The Common Agricultural Policy of the European Union the present and the future

EU Member States

point of view 



\section{INSTITUTE OF AGRICULTURAL AND FOOD ECONOMICS NATIONAL RESEARCH INSTITUTE}

\section{The Common Agricultural Policy of the European Union - the present and the future}

\section{EU Member States point of view}

Editors:

dr Marek Wigier

prof. dr hab. Andrzej Kowalski

Proceedings of the International Scientific Conference

"The Common Agricultural Policy of the European Union - the present and the future" Multi-Annual Programme 2015-2019

"The Polish and the EU agricultures 2020+. Challenges, chances, threats, proposals" 5-7 December 2017 Stare Jabłonki, Poland

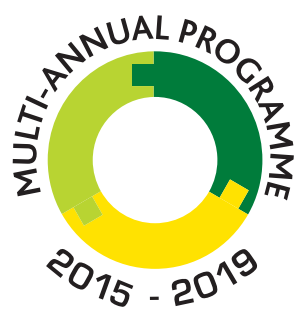

THE POLISH AND THE EU AGRICULTURES 2020+ CHALLENGES, CHANCES, THREATS, PROPOSALS

Warsaw 2018 
This monograph was prepared under the Multi-Annual Programme 2015-2019

"The Polish and the EU agricultures 2020+. Challenges, chances, threats, proposals".

The publication is a collection of selected papers delivered at the 22th edition of the International Scientific Conference organized by the Institute of Agricultural and Food Economics - National Research Institute. The theme of the conference was "The Common Agricultural Policy of the European Union the present and the future. The conference was placed on 5-7 December 2017 in Stary Jabłonki in Poland. Common Agricultural Policy was and still is one of the key pillars of European integration. Published in two volumes materials refer directly to the current and future of the CAP in EU and non EU member states, the strategic objectives and principles of agricultural policy for the agri-food sector and rural areas, address the issues of equilibrium between agriculture, forestry and land use, relate to the dilemmas for the EU budget and the CAP after 2020, CAP instruments and their adjustment, transformations of the rural economy and programming of the rural and agricultural policy, as well as productivity and production efficiency and tensions between sectoral action and between different models of territorial activities.

In the Scientific Committee of the Conference was participated: Prof. Andrzej Kowalski (IAFE-NRI, Poland), Prof. Drago Cvijanonivić (University of Kragujevac, Serbia), Prof. Thomas Doucha (IAEI, Czech Republic), Noureddin Driouech, PhD (CIHEAM, Italy), Prof. Szczepan Figiel (IAFE-NRI, Poland), Prof. Masahiko Gemma (Waseda University, Japan), Prof. Wojciech Józwiak (IAFE-NRI, Poland), Prof. Jacek Kulawik (IAFE-NRI, Poland), Prof. Yuriy Oleksiyovych Lupenko (IAE, Ukraina), Prof. Věra Majerová (CULS, Prague), Prof. Dimitre Nikolov (IAE, Bulgaria), Maire Nurmet, PhD (EMÜ, Estonia), Prof. Gabriel Popescu (ASE, Romania), Norbert Potori, PhD (AKI, Hungary), Prof. Włodzimierz Rembisz (IAFE-NRI, Poland), Piotr Szajner, PhD (IAFE-NRI, Poland), Prof. Alina Sikorska (IAFE-NRI, Poland), Prof. Jonel Subić (IAE, Serbia), Prof. Samuele Trestini (UNIPD, Italy), Prof. Olga Varchenko (Bila Tserkva National Agrarian University, Ukraine), Dipl.-Ing. Klaus Wagner (AWI, Austria), Marek Wigier, PhD (IAFE-NRI, Poland), Prof. Józef St. Zegar (IAFE-NRI, Poland)

In the Organising Committee of the Conference was participated: Małgorzata Bułkowska (IAFE-NRI, Poland), Anna Hankiewicz (IAFE-NRI, Poland), Joanna Jaroszewska (IAFE-NRI, Poland), Joanna Korczak (IAFE-NRI, Poland), Krzysztof Kossakowski (IAFE-NRI, Poland), Irena Mikiewicz (IAFE-NRI, Poland), Małgorzata Mikołajczyk (IAFE-NRI, Poland), Lech Parzuchowski (IAFE-NRI, Poland), Ewa Sierakowska (IAFE-NRI, Poland), Paulina Smakosz (IAFE-NRI, Poland), Leszek Ślipski (IAFE-NRI, Poland), Marek Wigier, PhD (IAFE-NRI, Poland).

Reviewers:

Professor Dimitre Nikolov, Institute of Agricultural Economics, Sofia, Bulgaria

Professor Gabriel Popescu, The Bucharest University of Economic Studies, Bucharest, Romania

Professor Samuele Trestini, University of Padva, Italy

Proofreader

Katarzyna Mikulska

Technical editors:

Joanna Jaroszewska, Barbara Pawtowska, Ewa Sierakowska, Kamila Tomaszewska,

Barbara Walkiewicz

Translated by

Summa Linguae S.A.

Cover Project

Leszek Ślipski

ISBN 978-83-7658-743-1

DOI: $10.30858 / \mathrm{pw} / 9788376587431$

Instytut Ekonomiki Rolnictwa i Gospodarki Żywnościowej

- Państwowy Instytut Badawczy

ul. Świętokrzyska 20, 00-002 Warszawa

tel.: (22) 5054444

faks: (22) 5054636

e-mail:dw@ierigz.waw.pl

http://www.ierigz.waw.pl 


\section{Contents}

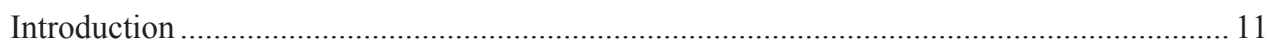

Dr Marek Wigier

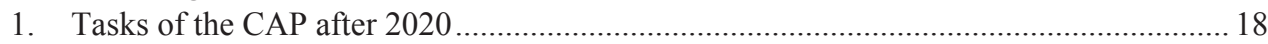

Dr hab. Julian Krzyżanowski

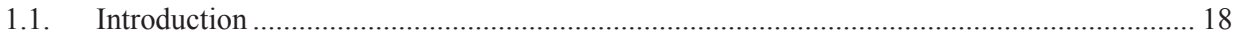

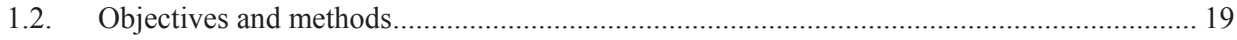

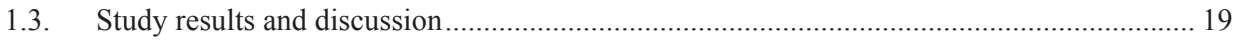

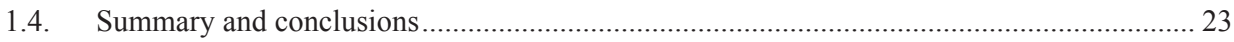

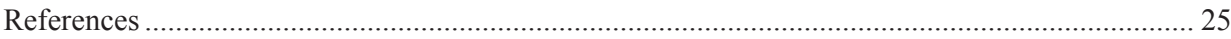

2. An assessment of the regional impacts of post-2020 CAP budgetary cuts on production

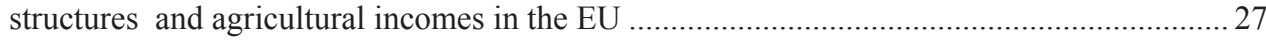

PhD Norbert Potori, PhD János Sávoly, PhD Szabolcs Biró

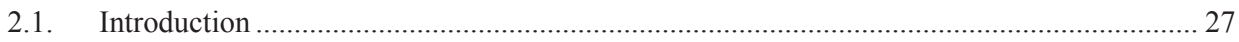

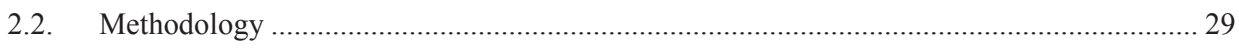

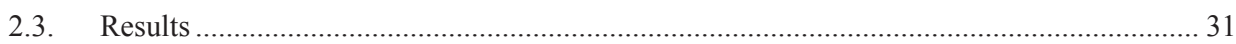

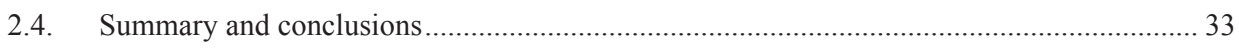

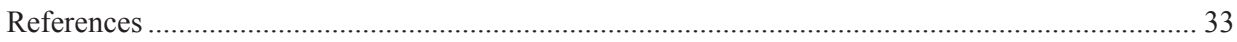

3. Is there room for financial instruments in the Common Agricultural Policy? Casus of

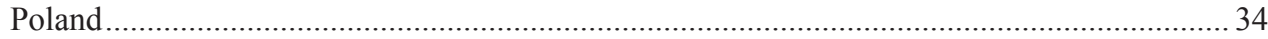

Prof. dr hab. Jacek Kulawik, PhD Barbara Wieliczko, PhD Michat Soliwoda

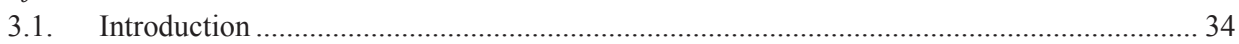

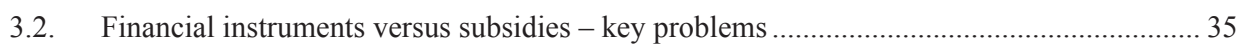

3.3. The use of financial instruments under the EU policy ......................................................... 37

3.4. Example of the use of FI in the 2014-2020 programming period ......................................... 38

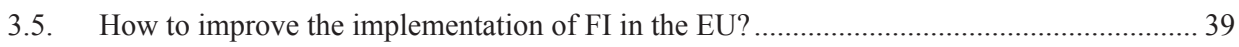

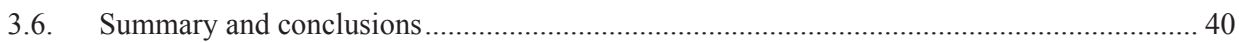

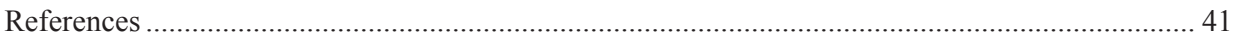

4. The past, present and future of the CAP - the Hungarian viewpoint ............................. 43

Dr Tamás Mizik

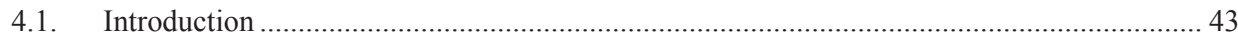

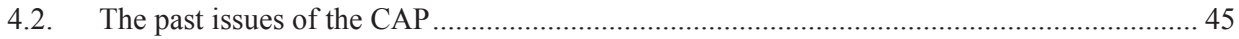

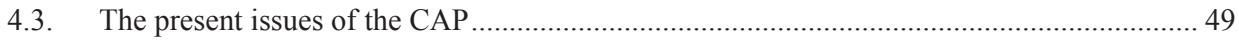

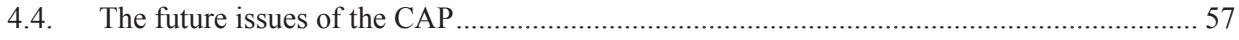

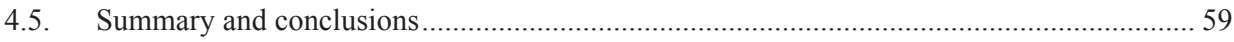

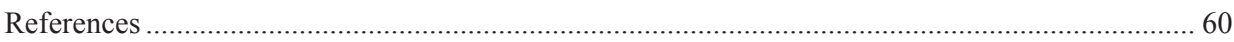


5. Going beyond the Rural Development Programme: a Master Plan for Austria's rural areas in the framework of the CAP

Dip.-Ing. Klaus Wagner

5.1. Introduction

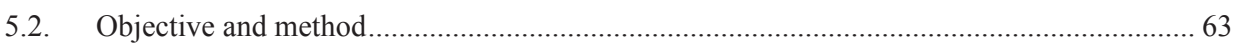

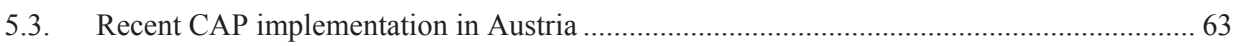

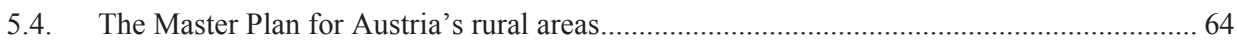

5.5. CAP in the system of the EU policy objectives and in the view of regional science

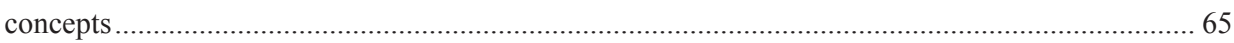

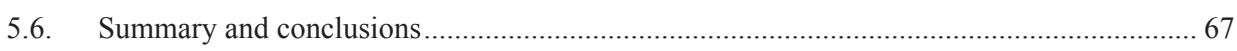

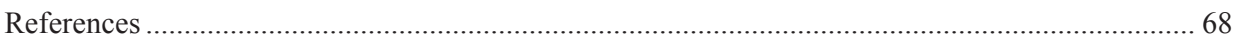

6. Possibilities to connect the Romanian agricultural research to the market requirements 69 Prof. Gabriel Popescu

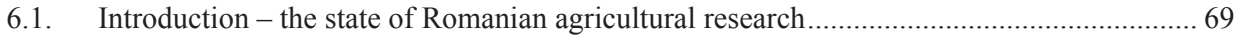

6.2. The problems faced by agricultural research since 1990 ..................................................... 71

6.3. Possible solutions for the recovery of Romanian agricultural research ................................ 76

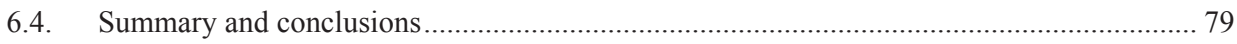

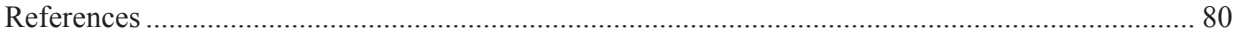

7. Price relationships of the production factors as exogenous determinants of production in agriculture.

Prof. dr hab. Włodzimierz Rembisz, PhD Adam Waszkowski

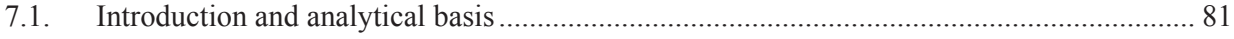

7.2. Relationships of prices of the capital, labour and land factors - hypothetical approach...... 83

7.3. Relationships of prices of the capital, labour and land factors - empirical approach .......... 84

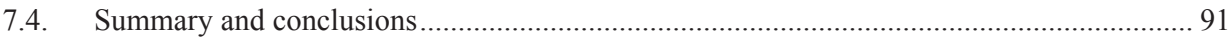

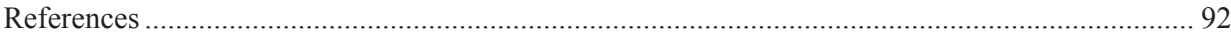

8. Effects of direct payments on agricultural development in Bulgaria ............................. 93 PhD Bozhidar Ivanov

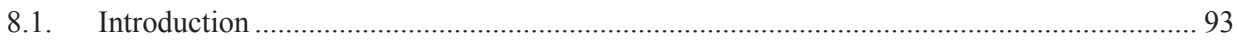

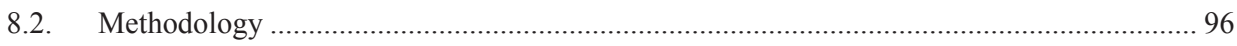

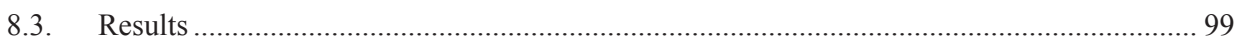

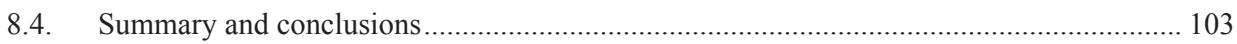

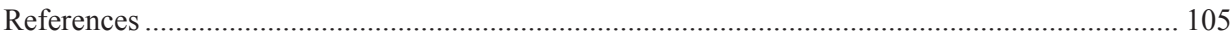

9. Re-adjusting risk management within the CAP: evidences on the implementation of the

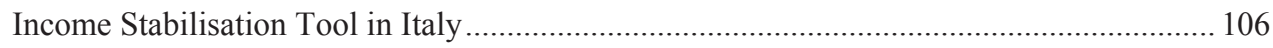
Prof. Samuele Trestini, PhD Elisa Giampietri

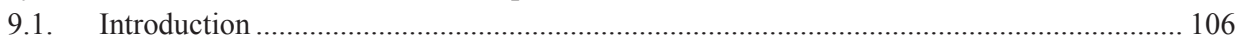

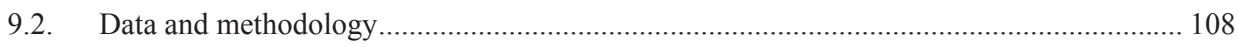




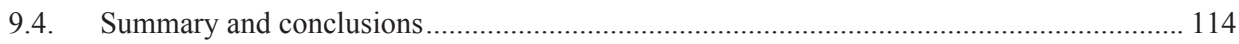

References

10. Comparison of risk management tools under the CAP of the EU, the US Farm Bill

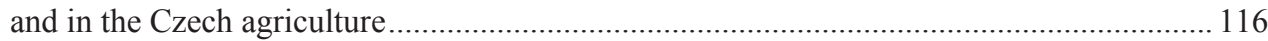
Ing. Václav Vilhelm, CSc., Ing. Sumudu Namali Gouri Boyinová, PhD Jindřich Špička

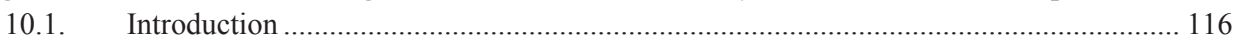

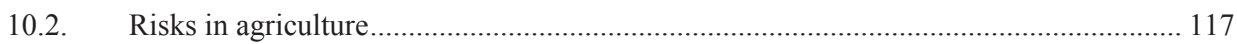

10.3. Risk management policy in the United States Farm Bill 2014 _..................................... 118

10.4. Risk management policy of the European Union's CAP ................................................ 119

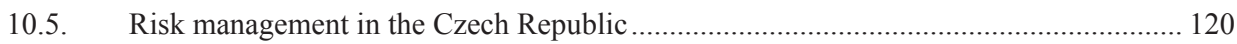

10.6. Comparative analysis of risk management policies ........................................................ 121

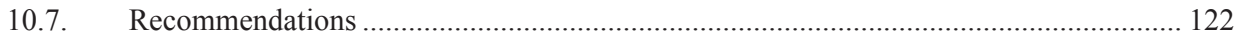

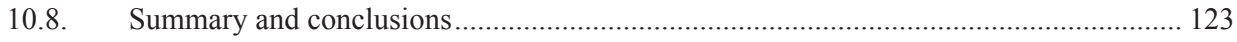

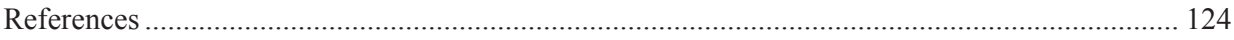

11. Factors determining the crop insurance level in Poland taking into account the level

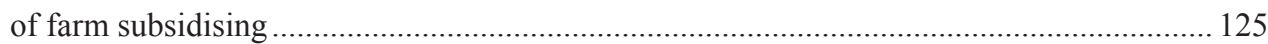

Prof. Adam Was, PhD Pawet Kobus

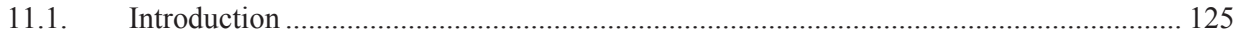

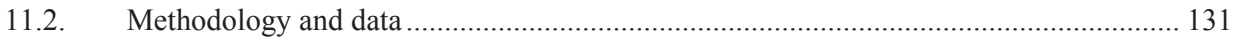

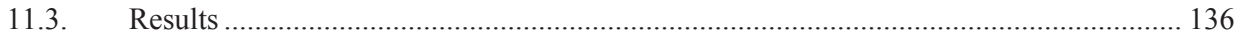

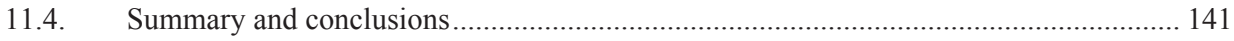

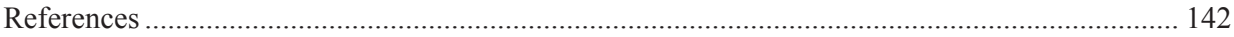

12. Farms and agricultural enterprises for development of sustainable and smart cooperatives: a multifactor approach using digital farm management ............................... 147 Prof. dr habil Adriana Mihnea, Prof. dr Dimitre Nikolov, dr Krasimir Kostenarov

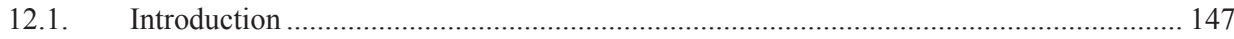

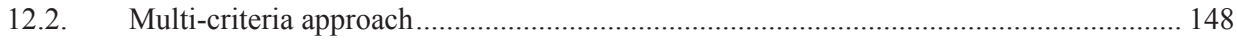

12.3. Construction of Farm Management Model ................................................................ 150

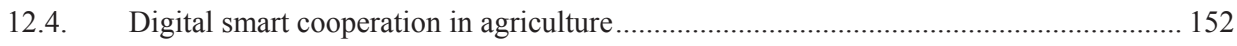

12.5. Application of the ANP Farm Management Model ....................................................... 154

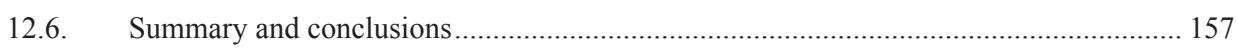

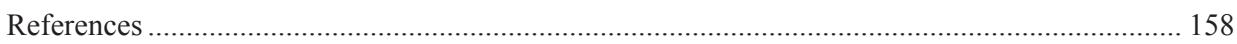

13. Brexit - potential implications for the Polish food sector .............................................. 159

Dr Katarzyna Kosior, Dr Łukasz Ambroziak

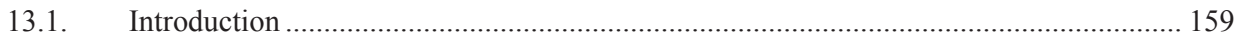

13.2. Negotiations on Brexit - what should be the model of the future relations? ..................... 161

13.3. The future of the EU finances and the CAP in the context of Brexit .............................. 163 
13.4. Impact of possible changes in the CAP budget on the net balance of Poland and transfers to the Polish agriculture.

13.5. The potential impact of Brexit on agri-food trade between Poland and the United

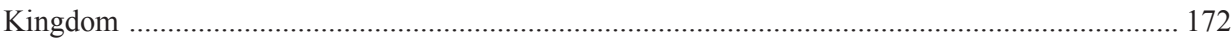

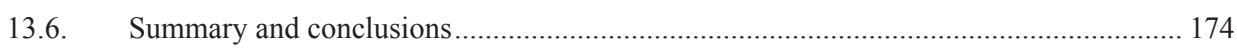

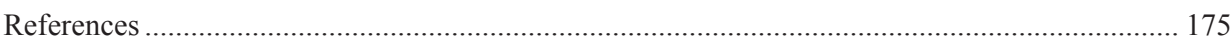

14. The Transatlantic Trade and Investment Partnership (TTIP): a threat or an opportunity for the EU-Mediterranean agriculture and agri-food sector? An exploratory survey ........... 177 Dipl.-Ing. Katja Pietrzyck, PhD Noureddin Driouech, Prof. Brigitte Petersen

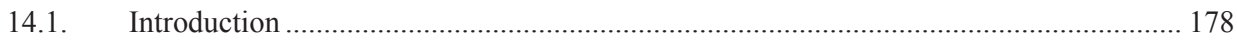

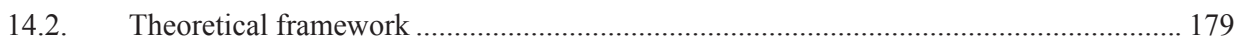

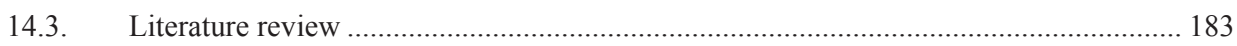

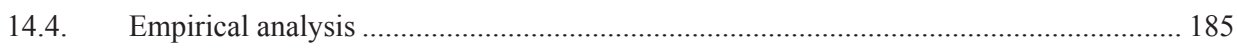

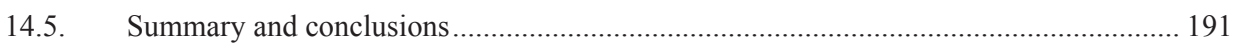

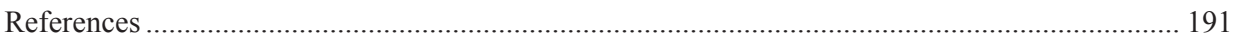

Appendix I: Overview of trade statistics regarding selected products ........................................... 195

15. The concept of short supply chains in the food economy............................................. 196

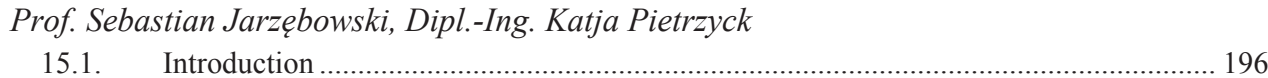

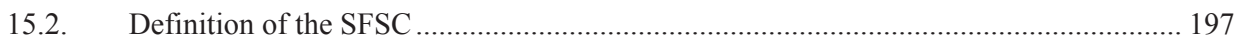

15.3. Development of short supply chains in Europe............................................................. 201

15.4. Global context of European short supply chains ........................................................... 205

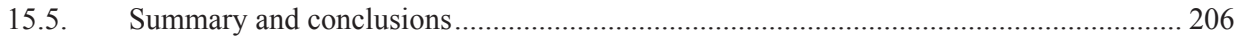

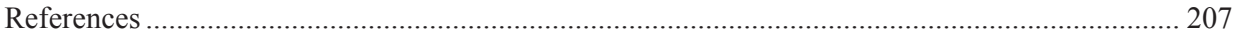

16. The CAP implementation in Wallonia - today performance and questions for the future -

A brief supplementary comment from Warmia and Mazury perspective............................. 209

PhD Philippe Burny, PhD Benon Gazinski

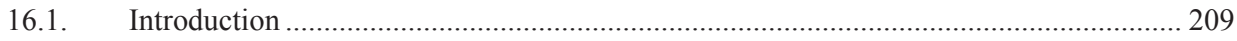

16.2. Implementation of the green payment in Wallonia in 2015 ........................................ 210

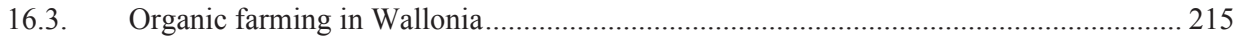

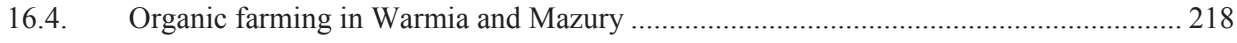

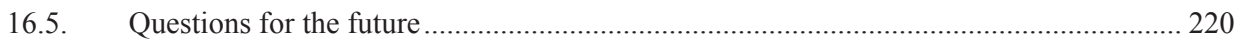

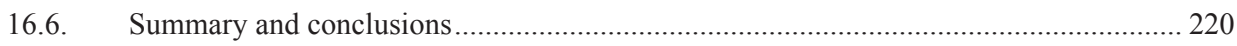

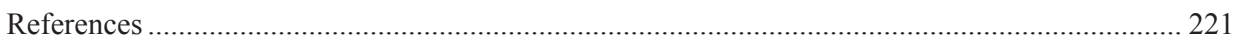

17. Afforestation of agricultural land financed from the RDP 2014-2020 ....................... 224

PhD Marek Zieliński

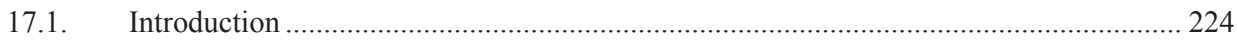

17.2. Natural farming conditions in Poland in regional terms................................................. 225 
17.3. The impact of natural farming conditions in Poland on the economic situation and the possibility of afforestation on farms

17.4. Land afforestation financed from the RDP 2014-2020 in regional terms

17.5. Importance of land afforestations financed under the RDP 2014-2020 in the EU climate policy for 2021-2030.

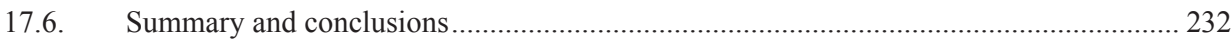

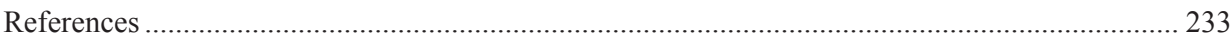

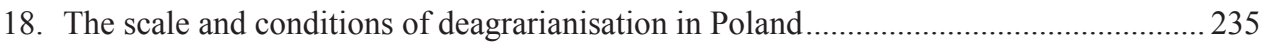

PhD Michat Dudek, PhD Bożena Karwat-Woźniak

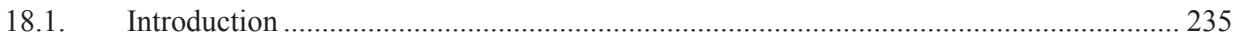

18.2. The conditions of the decrease in employment in agriculture ......................................... 236

18.3. The change in the scale of employment in agriculture in Poland and its conditions....... 238

18.4. The instruments of the Cohesion Policy and agriculture and rural development of the EU

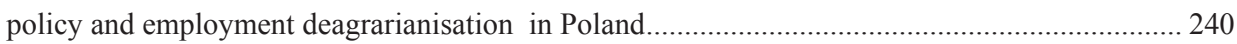

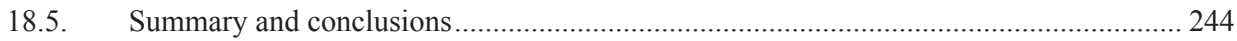

References 245

19. Socio-economic and environmental parameters and results of rural development under the CAP: the case of Bulgaria ................................................................................................ 247 Prof.dr.hab. Julia Doitchinova, Prof.dr.hab. Ivan Kanchev, Ass.Prof. Ralitsa Terziyska PhD, Ass.Prof. Kristina Todorova PhD

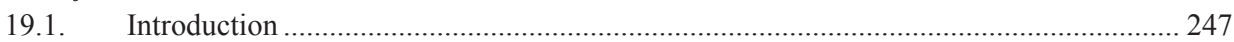

19.2. Changes in Bulgarian rural areas - socio-economic and environmental aspects................ 248

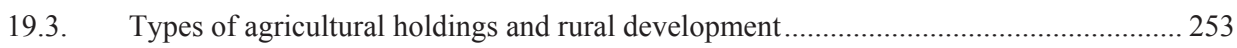

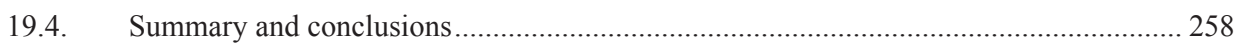

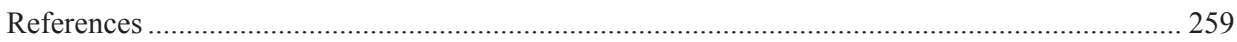

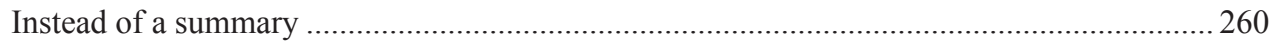

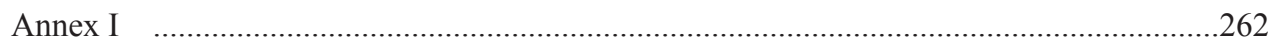




\title{
7. Price relationships of the production factors as exogenous determinants of production in agriculture
}

\author{
Prof. dr hab. Włodzimierz Rembisz, PhD Adam Waszkowski \\ Institute of Agricultural and Food Economics - National Research Institute, \\ Warsaw, Poland \\ Rembisz@ierigz.waw.pl,Waszkowski@ierigz.waw.pl
}

DOI: $10.30858 / \mathrm{pw} / 9788376587431.7$

\begin{abstract}
In this article, attention is focused on the prices of production factors (capital, labour and land) and their relationships. We indicate here their exogenous character based on the author's analytical approach. In addition, we derive the dependencies, while drawing from the theory of microeconomics and the producer choice theory. Empirical verification for the selected EU countries covered the pairs of levels of these prices in the agricultural sector. Finally, these relationships determine the production techniques and their changes, that is, the relationships of the involved production factors necessary to obtain a certain production level ${ }^{8}$.
\end{abstract}

Keywords: production factors, Total Factor Productivity (TFP), microeconomic behaviour

JEL codes: D33, D24, D01

\subsection{Introduction and analytical basis}

In order to identify the exogenous factors which are of our interest from the point of view of the set objective and which influence the production techniques, we are starting with the definition of the production efficiency (PE), which is exceptionally given here in current prices. In an analytical way, it can be noted as a quotient between income and the cost of using production factors (capital, labour and land for the given level of the agricultural production on a producer or agriculture scale at current prices [Bezat-Jarzębowska and Rembisz, 2013]:

$$
E P=\frac{p_{i} y_{i}}{K_{i} c_{K}+L_{i} c_{L}+Z_{i} c_{Z}}
$$

\footnotetext{
${ }^{8}$ This article is a continuation of the studies carried out by the Team under the Multi-Annual Programme 2015-2019 at the IAFE-NRI. The issue of the exogenous factors was discussed in more detail in the monograph by Rembisz W., Waszkowski A., Egzogenne uwarunkowania produkcji w rolnictwie - ceny czynników produkcji i wybrane wskaźniki makroekonomiczne, Program Wieloletni 2015-2019, nr 69, IERiGŻ-PiB, Warszawa. The article presents a synthetic approach to the above-mentioned monograph, presented at the Conference organised by the IAFE-NRI and entitled "The Common Agricultural Policy of the European Union - the present and the future" which was held on 5-7.12.2017.
} 
where:

$i$ - means the agricultural producer,

$p$ - prices of agricultural products,

$c_{K}-$ price of the capital factor,

$c_{L}-$ price of the labour factor,

$c_{Z}-$ price of the land factor.

In analytical terms, the time subscript $t$ is omitted.

Assuming the zero profit conditions and the homogeneity of the function at the given time, the above equality, in the conditions of competitive equilibrium in the product market, may be noted as:

$$
p_{i} y_{i}=K_{i} c_{K}+L_{i} c_{L}+Z_{i} c_{Z}
$$

When both sides of the statement are converted to a logarithm, this enables an approximate notation ${ }^{9}$ of the production efficiency in value terms as a sum:

$$
\ln p_{i}+\ln y_{i} \approx \ln K_{i}+\ln c_{K}+\ln L_{i}+\ln c_{L}+\ln Z_{i}+\ln c_{Z}
$$

Determining the $\partial$ partial derivatives and omitting the time indices allows to make the following notation:

$$
\frac{\partial y}{y}-\left\{\frac{\partial K}{K}+\frac{\partial L}{L}+\frac{\partial Z}{Z}\right\}=\left\{\frac{\partial c_{K}}{c_{K}}+\frac{\partial c_{L}}{c_{L}}+\frac{\partial c_{Z}}{c_{Z}}\right\}-\frac{\partial p}{p}
$$

In analysing the above identity, we can divide it [Bezat-Jarzębowska and Rembisz, 2016]. The left side of the equation is responsible for the endogenous, conventional factors dependent on agricultural producers in the sense of choices they made to maximise their own objective function. These factors are related to the production efficiency and its changes in the sense of TFP. The factors listed on the right side of the equation are the exogenous factors. These are the relationships between product prices (prices which are either paid or received) and prices of the production factors (in fact, their services from the given factor involvement) identified in the market of production factors as we showed above (this is equivalent to the idea of price scissors).

The obtained exogenous dependencies are the indices of the most important economic parameters, important from the point of view of the agricultural producer. As a sector, agricultural producers are price-takers. The price scis-

\footnotetext{
${ }^{9}$ This is a sort of approximation, assuming that we deal with the sum of two-factor production functions expressed as $p_{1} y_{1}=K_{i} c_{K}, p_{2} y_{2}=L_{i} c_{L}$ and $p_{3} y_{3}=Z_{i} c_{Z}$, while $p_{i} y_{i}=\sum_{i=1, \ldots, 3} p_{i} y_{i}$, i.e. the identity is an approximation of two-sided conversion into a logarithm assuming the sum of one-factor production functions.
} 
sors arrangements indicated in the above inequality are determined by market mechanisms, self-regulatory processes on the demand and supply sides, and are susceptible to the impact of the pursued economic policy or intervention measures. In this context, and in line with the Jovens' interpretation, producers adapt to prices. This relationship is not transitive - the prices of products do not adapt to the costs of production in the free competitive market. It happens where intervention measures are applied, for example, in agricultural markets.

The adaptations are related to an improvement in the efficiency, especially to an improvement in the productivity of individual (endogenous) factors. As we have shown, the relationships of prices of the production factors and their changes are not, in fact, dependent on the agricultural producer and in each market model they are exogenous for the agricultural producer. The above-mentioned improvement in the efficiency of the production process may take place as a result of substitution, for example, of involving the labour factor with increasing the involvement of the capital factor [Rembisz, 2005] and by making progress understood as an increase in innovation, knowledge, managerial and organisational skills.

\subsection{Relationships of prices of the capital, labour and land factors - hypothetical approach}

As a result of the assumptions showing the price evolution for the labour, capital and land factors, hypothetical Figure 1 was adopted. It shows the relationship of prices of the production factors: the price of the labour factor whose remuneration increases, the capital factor which becomes relatively cheaper and the price of the land factor. The final relationships should be referred to prices of services of these factors in the production process.

The adopted hypothetical assumptions related to prices of the production factors are also justified by the theories and observations of the economic growth and development. They also stem from the relationship of their scarcity as a fundamental economic right.

As a result of the non-agricultural demand for the land factor, i.e. urbanisation processes, residential housing, environmental, tourism and recreation issues, etc., it is becoming increasingly scarce also in absolute terms as far as the agricultural use is concerned. Similar dependencies are observed in the non-agricultural demand for the labour factor. On the other hand, the increase is characteristic of the supply of the (real) capital factor which makes it relatively and also absolutely cheaper and cheaper. This results in an increase in its use in agriculture. Together, this leads to changes in production techniques, generally towards those which are more and more capital inten- 
sive while labour- and land-saving. We do not analyse this here. We refer only to price-related (production factor prices), exogenous determinants of these production techniques changes.

Figure 1. Hypothetical assumption as to the price evolution for the labour, capital and land factors

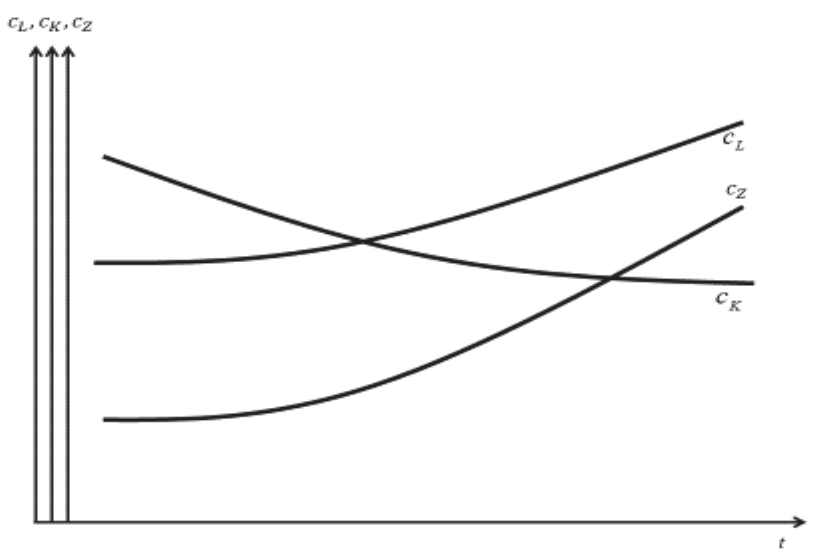

Source: own study.

\subsection{Relationships of prices of the capital, labour and land factors - empirical approach}

As shown in Figure 1, the hypothetical relationships of prices of the capital and labour factors and of the land and capital factors have been verified empirically. The following time series were used for this purpose:

- $\quad$ Price of the capital factor $C_{K}$ - defined on a proxy basis as the baseline interest rate on the alternative involvement basis (in terms of lost profits [Kleinhanss, 2014]); based on the Eurostat database;

- $\quad$ Price of the labour factor $c_{L}$ - defined as the average hourly remuneration expressed in EUR; based on the Eurostat database;

- $\quad$ Price of the land factor $c_{Z}$ - for 2005, 2007, 2010 and 2013; taken from the Eurostat database.

Final verification covered the years between 2004 and 2013, which results straight from the data availability.

The following empirical figures show the price of the capital factor and the price of the labour factor for the selected EU countries ${ }^{10}$.

\footnotetext{
${ }^{10}$ Empirical studies on this issue were presented in more detail in the monograph by Rembisz W., Waszkowski A., Egzogenne uwarunkowania produkcji w rolnictwie - ceny czynników produkcji i wybrane wskaźniki makroekonomiczne, Program Wieloletni 2015-2019, nr 69, IERiGŻ-PiB, Warszawa.
} 
Figure 2. Labour factor price and capital factor price in agriculture in Poland

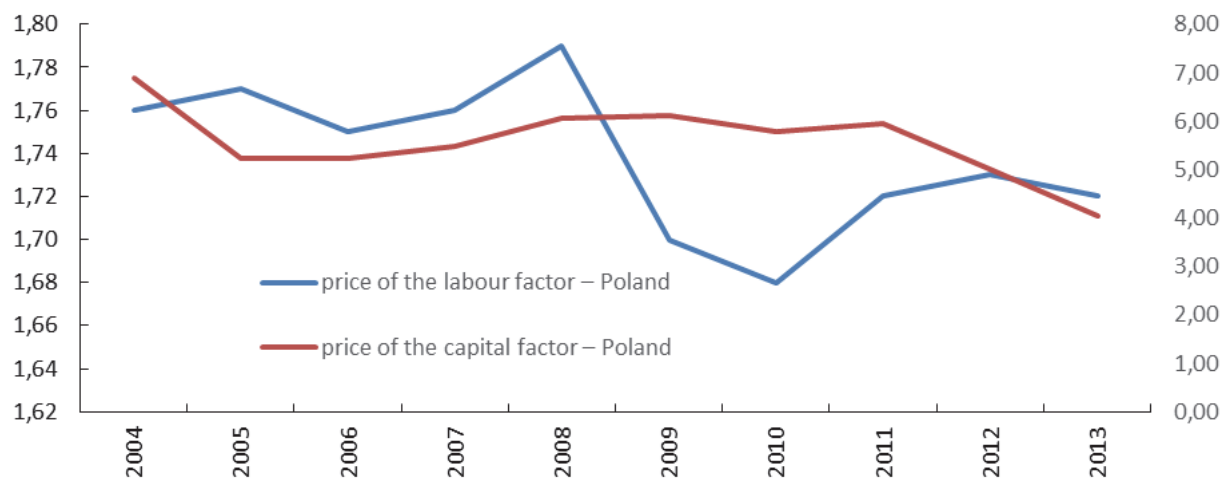

Source: own study based on the Eurostat data.

Figure 3. Labour factor price and capital factor price in agriculture in the EU

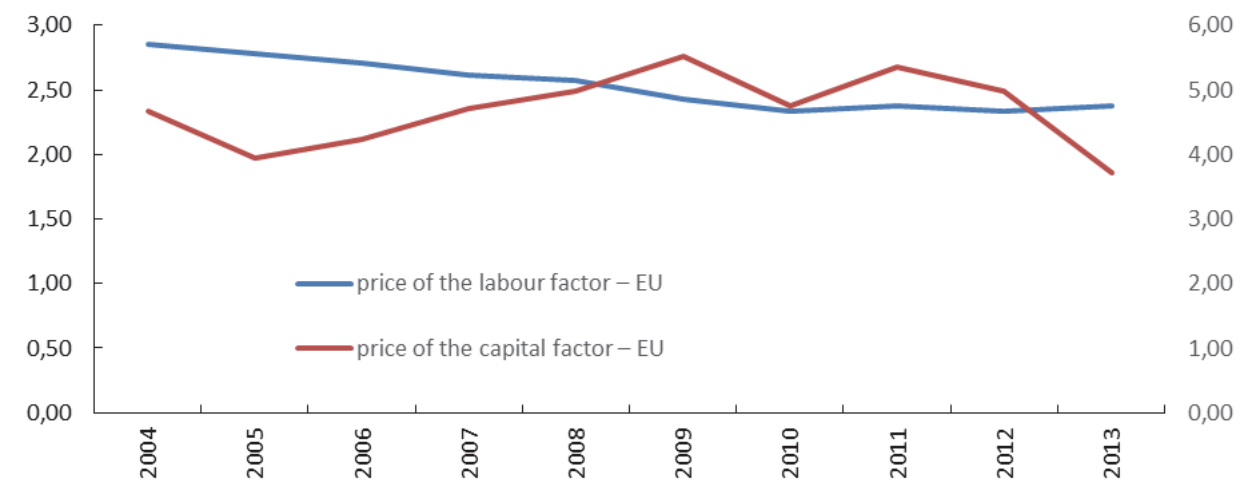

Source: own study based on the Eurostat data.

Figure 4. Labour factor price and capital factor price in agriculture in Germany

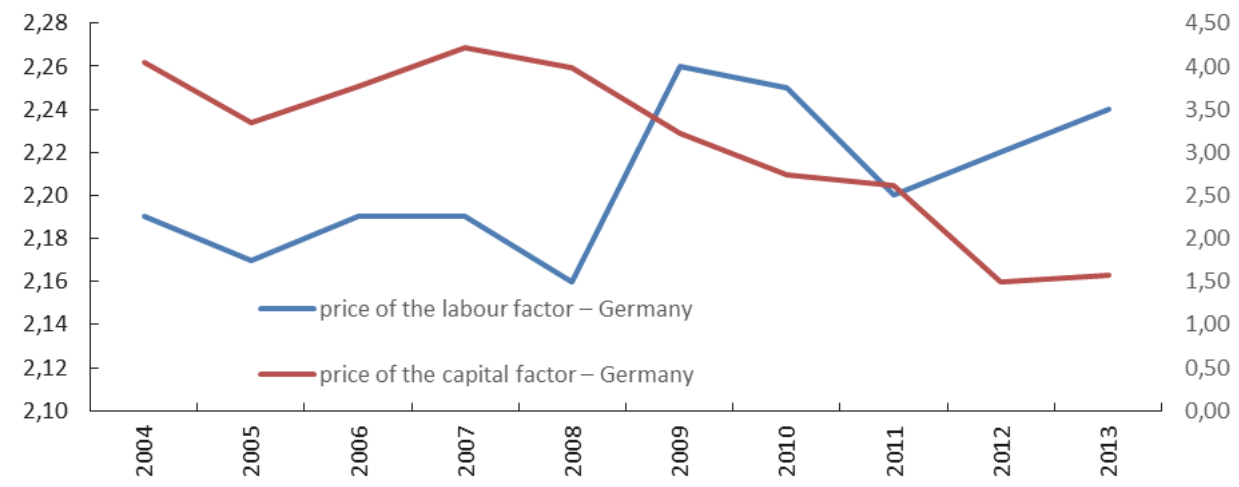

Source: own study based on the Eurostat data. 
Figure 5. Labour factor price and capital factor price in agriculture in France

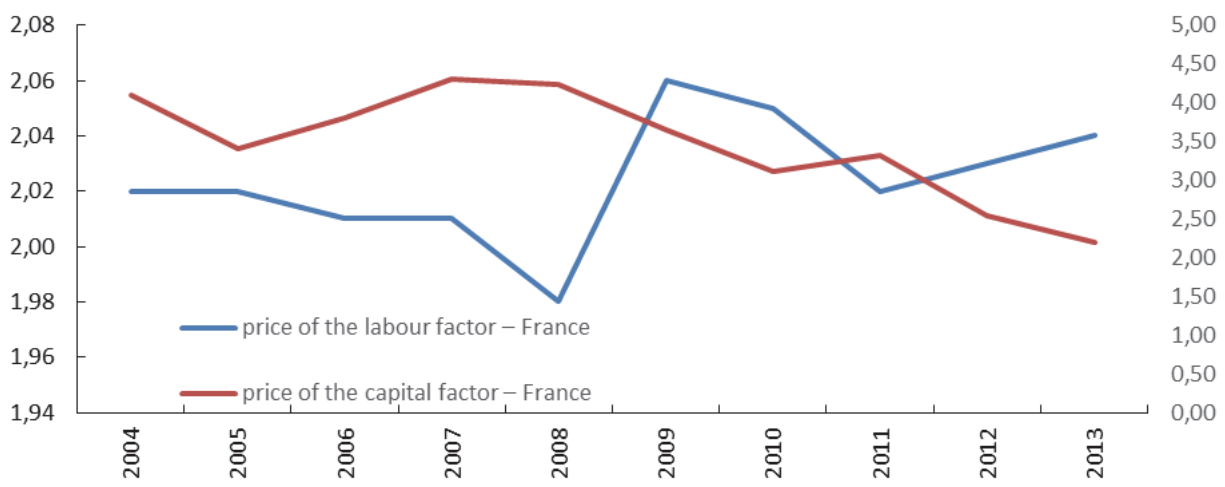

Source: own study based on the Eurostat data.

Figure 6. Labour factor price and capital factor price in agriculture in Great Britain

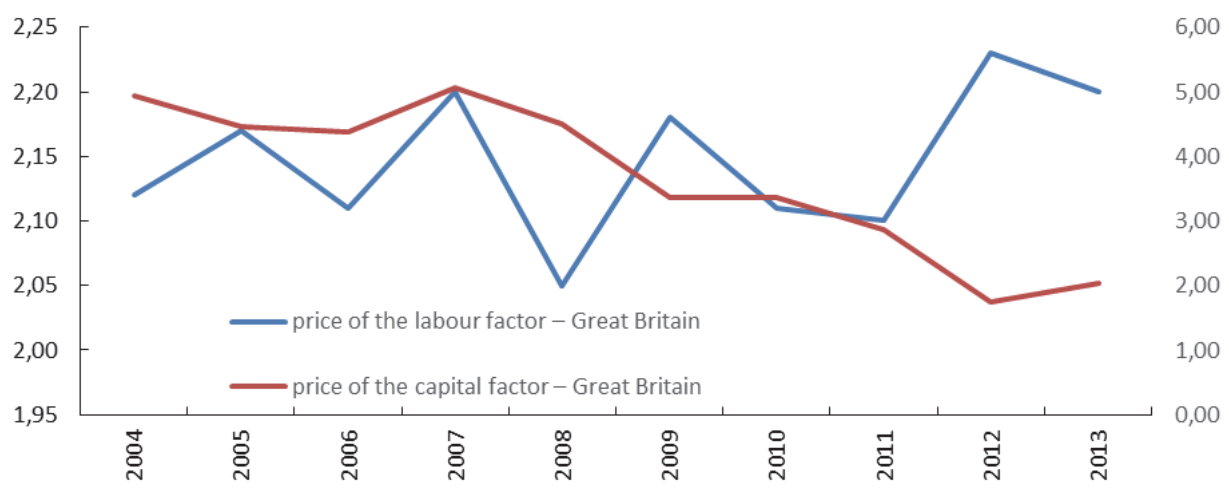

Source: own study based on the Eurostat data.

Figure 7. Labour factor price and capital factor price in agriculture in Lithuania

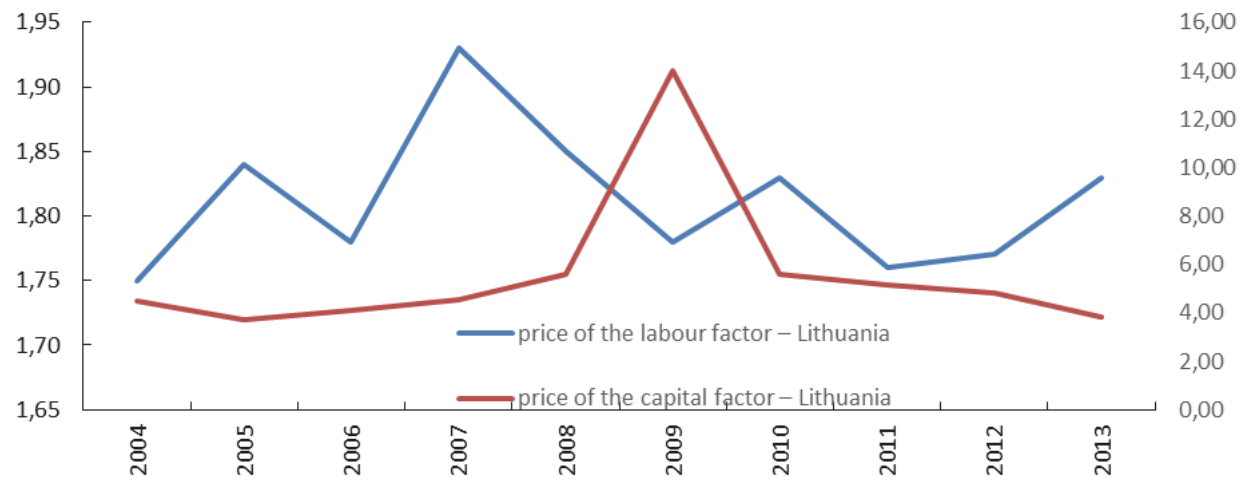

Source: own study based on the Eurostat data. 
Figure 8. Labour factor price and capital factor price in agriculture in the Netherlands

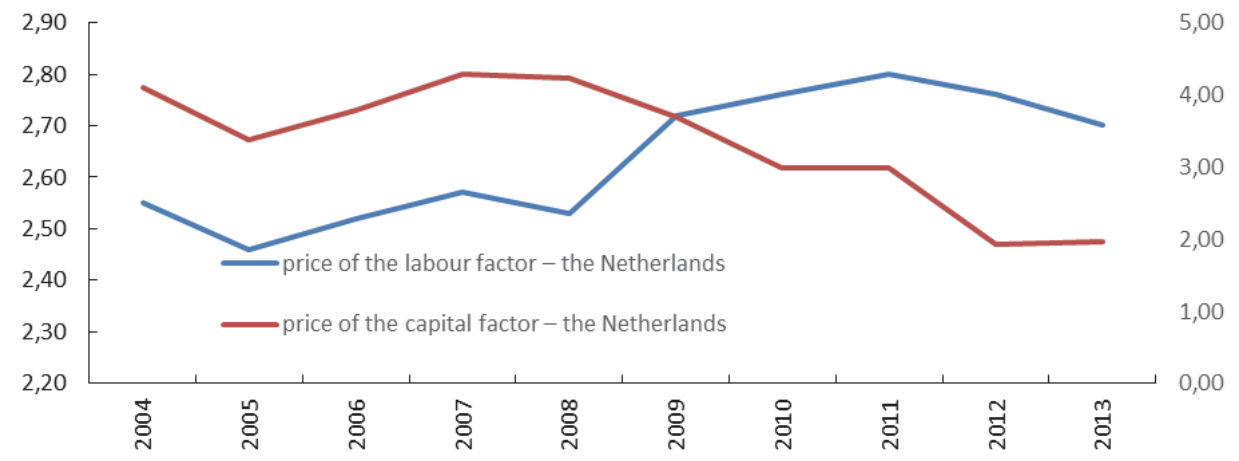

Source: own study based on the Eurostat data.

Figure 9. Labour factor price and capital factor price in agriculture in Hungary

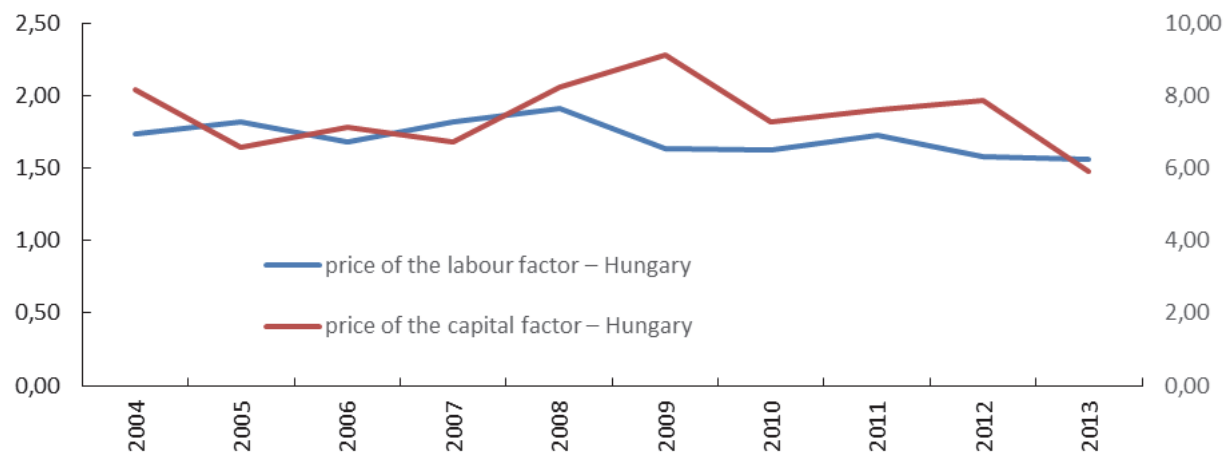

Source: own study based on the Eurostat data.

Figure 10. Labour factor price and capital factor price in agriculture in Slovakia

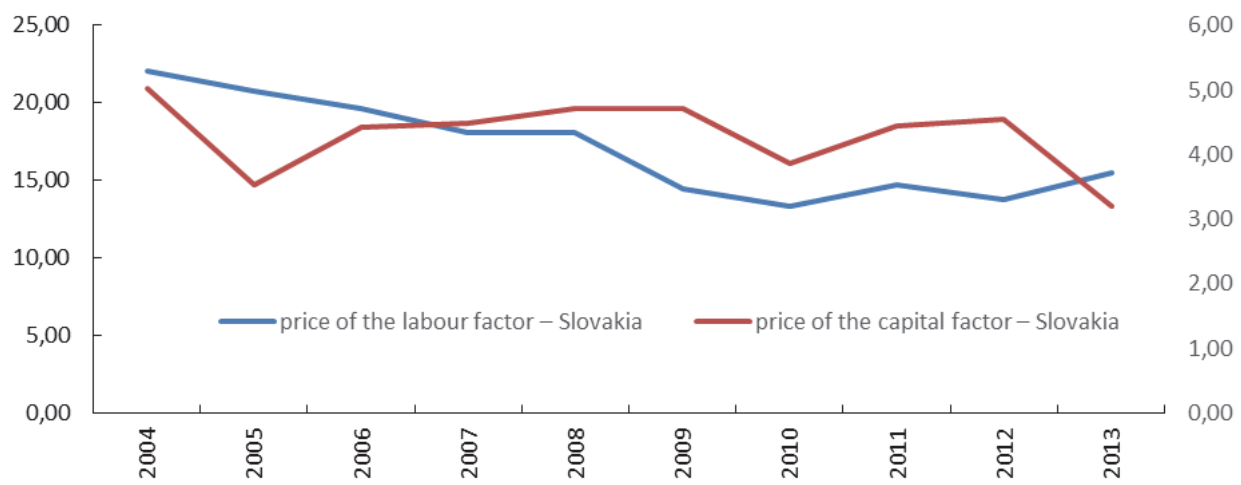

Source: own study based on the Eurostat data. 
The above-mentioned visualisations confirm the adopted hypothetical assumptions that were derived from the theoretical and analytical approaches. As we have shown, we verify the indicated dependencies as regards the trends. In Figures 2-10, it can be observed that the price of the labour factor in relation to the price of the capital factor is higher and higher. The opposite directions are clearly visible since 2008 . This may indicate the occurrence of substitution processes in the economy in the context of production techniques. This is, naturally, consistent with the assumptions adopted. This is also confirmed by the growth models in agriculture [Rembisz and Floriańczyk, 2014]:

- $\quad$ models based on the intensification theory [Woś and Tomczak, 1983],

- Hayami-Ruttan models,

- $\quad$ Kuznetz models in broader terms.

In this context, we conclude that the amount of the capital factor is increasing. This is due to the economic and industrial development. Therefore, in accordance with the principle of the level of scarcity, the capital factor is becoming cheaper and cheaper in absolute terms and in terms of the price of the labour factor. This is due to the fact that it becomes more expensive as a result of the general development. This determines the decrease in its availability for the agricultural sector due to the competitive employment outside that area.

These price relationship changes are also determined by an improvement in the productivity of both production factors. By assumption, the increase in the productivity is, in fact, due to the rise in the price of the given factor(s) provided that the assumption stating that the endogenous relationships are induced by the exogenous relations is fulfilled.

The price relationships of the capital and land factors are presented in the following Figures 11-18.

Figure 11. Land factor price and capital factor price in agriculture in Poland

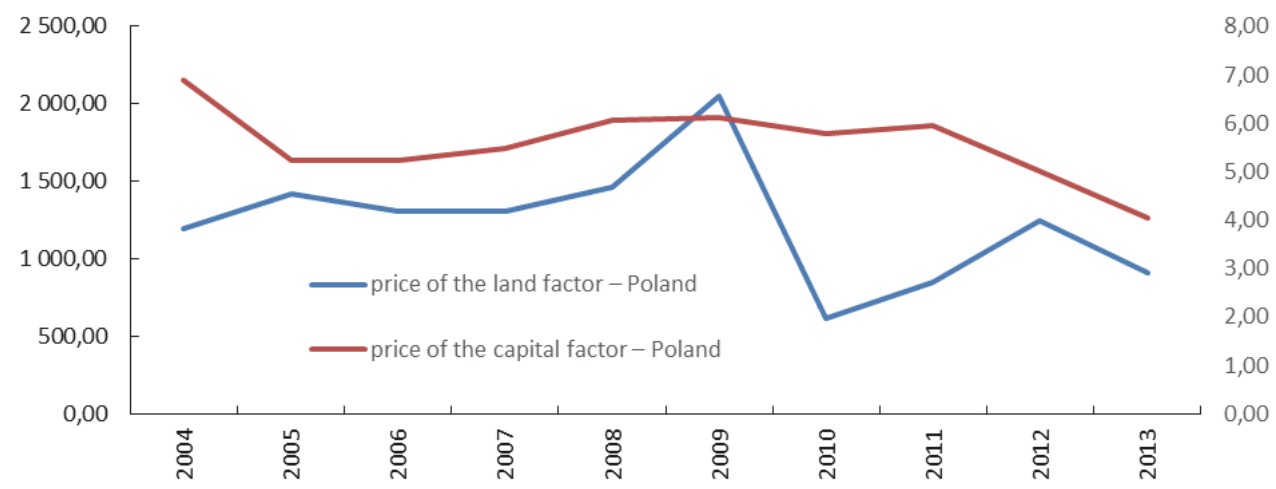

Source: own study based on the Eurostat data. 
Figure 12. Land factor price and capital factor price in agriculture in the EU

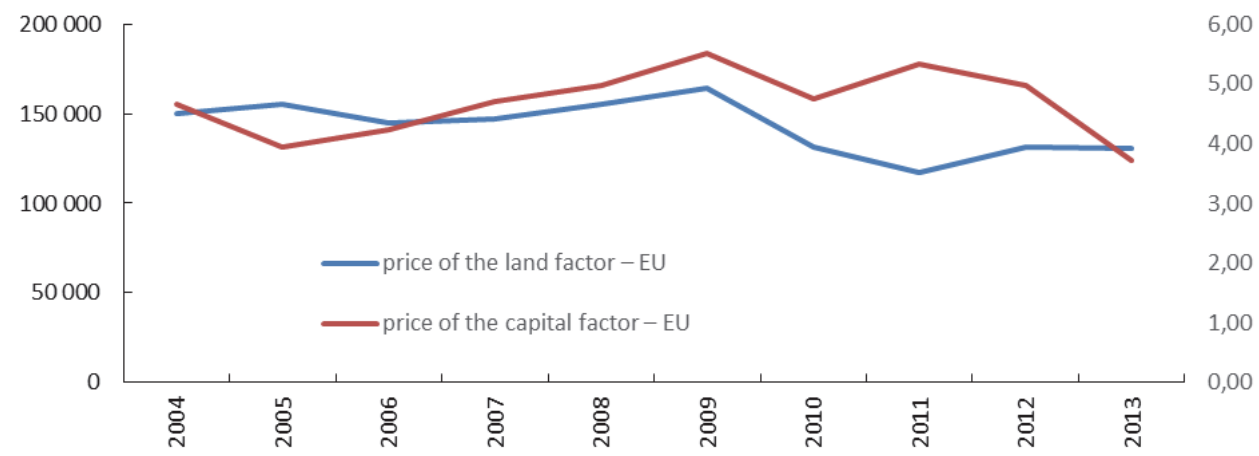

Source: own study based on the Eurostat data.

Figure 13. Land factor price and capital factor price in agriculture in Germany

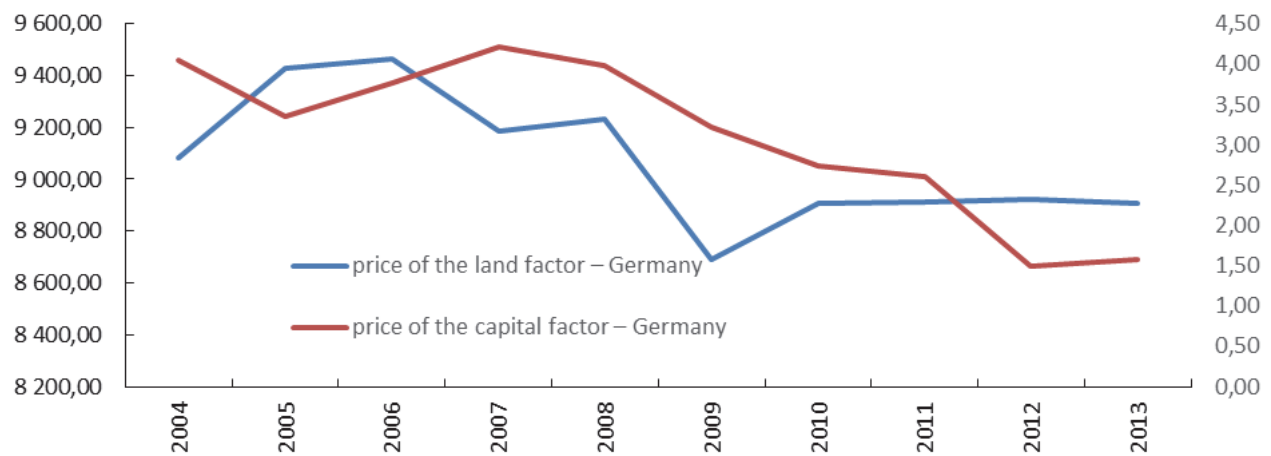

Source: own study based on the Eurostat data.

Figure 14. Land factor price and capital factor price in agriculture in France

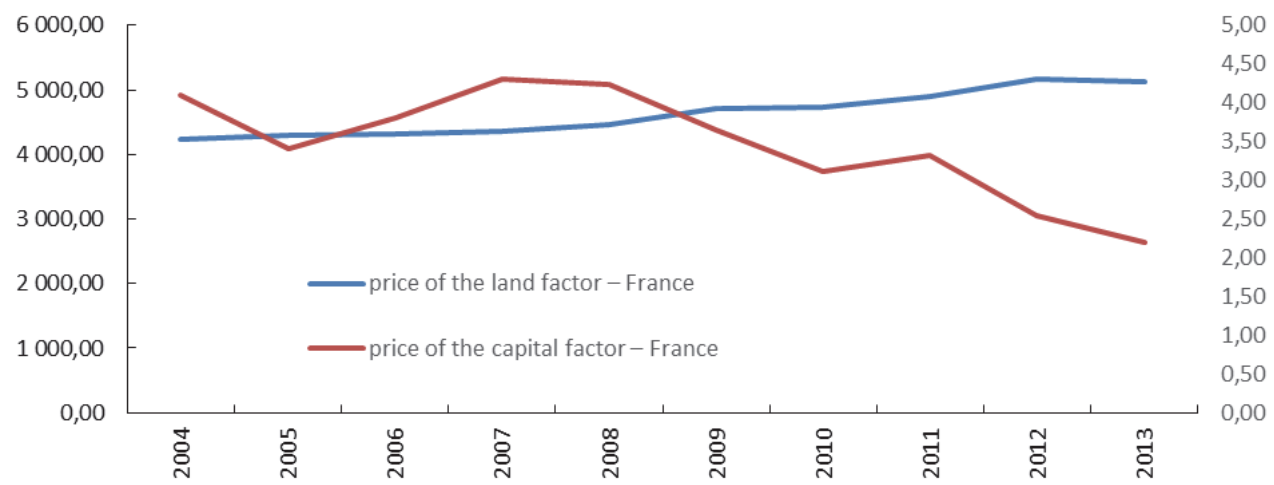

Source: own study based on the Eurostat data. 
Figure 15. Land factor price and capital factor price in agriculture in Great Britain

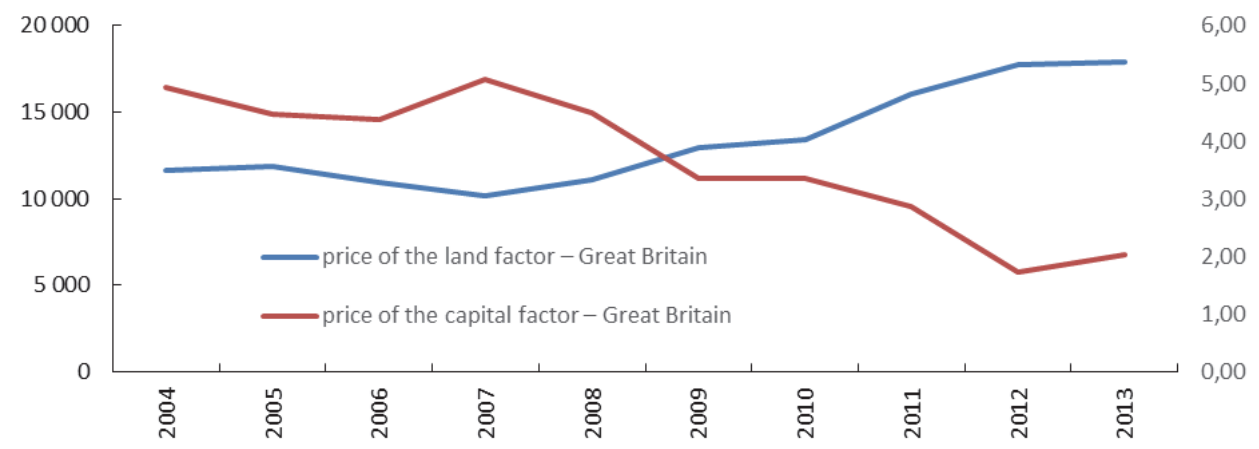

Source: own study based on the Eurostat data.

Figure 16. Land factor price and capital factor price in agriculture in Lithuania

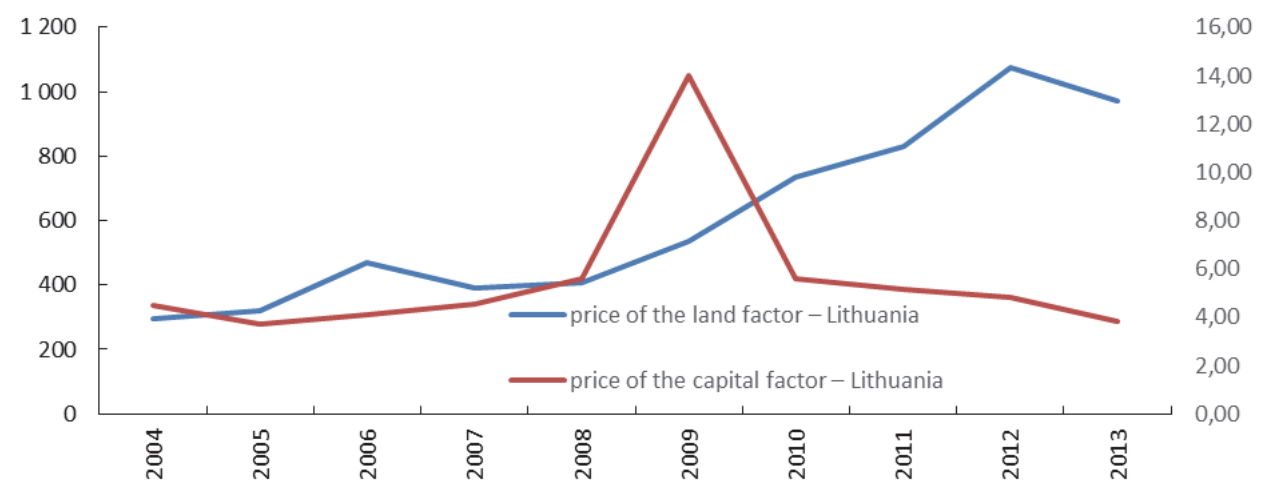

Source: own study based on the Eurostat data.

Figure 17. Land factor price and capital factor price in agriculture in the Netherlands

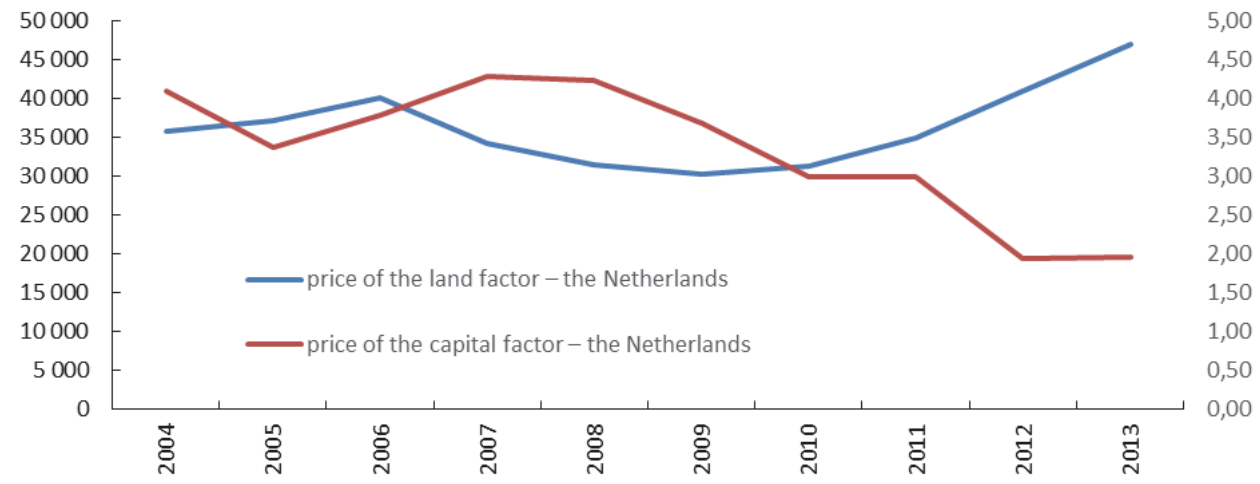

Source: own study based on the Eurostat data. 
Figure 18. Land factor price and capital factor price in agriculture in Slovakia

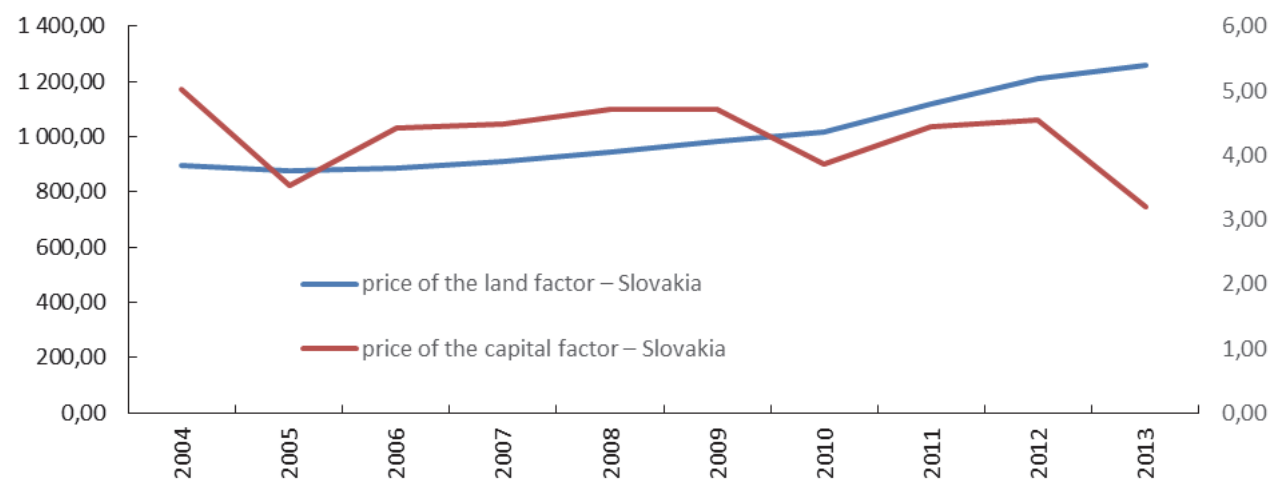

Source: own study based on the Eurostat data.

Also, in the case of the price relationships of the land and capital factors, the empirical charts obtained are in line with the analytical assumptions and hypotheses derived. As a general rule, the trends in the price changes of both factors are opposite - the time series charts intersect. The reasons should be seen in the same areas and theories as for the price relationships of the capital and land factors.

\subsection{Summary and conclusions}

In the article, the main focus is on the analytical identification of the exogenous factors, based directly on the theory of microeconomics and production function. It was indicated that the price relationships of the capital, labour and land factors determine the production techniques. Based on the author's model approach, the assumptions were adopted as to the price relationships of these factors and were subsequently empirically verified for the selected EU countries.

Empirical analyses were carried out for the average values of the EU countries and for Poland, Germany, France, Great Britain, Lithuania, the Netherlands and Slovakia. In the case of the first pair of price relationships, we expected the falling price of the capital factor in relation to the price of the labour factor. As to the trends, these assumptions are best illustrated by the time series for the Netherlands, France and Great Britain, and thus the developing countries with a dominant share of the service sector in production. In the case of Hungary and Slovakia, these changes start evolving according to the expectations derived from the theoretical approach only after 2013. Poland is not an exception - the expected trends as to the falling price of the capital factor have been observed since 2009, while the price of the labour factor has been rising since 2008. For the second pair of price relationships: the capital factor and the land factor, we also did not observe any deviations from the derived hypotheses. For each ana- 
lysed country, these price scissors "are opening" to the outside of the coordinate system. This is clearly an exogenous determinant of changes in the production techniques implicitly consistent with the views contained in the literature. It must also be added that the the second endogenous determinant of changes in the production techniques are changes in the productivity of the production factors. These are issues to be discussed on a different occasion.

\section{References}

1. Bezat-Jarzębowska, A., Rembisz, W. (2013). Ekonomiczny mechanizm kształtowania dochodów producentów rolnych, IERiGŻ-PIB, Warszawa.

2. Bezat-Jarzębowska, A., Rembisz, W. (2015a). Endo-i egzogenne źródła wzrostu gospodarczego w rolnictwie - zarys probematyki. Roczniki Naukowe SERiA, vol. 17, issue 6, pp. 19-24.

3. Bezat-Jarzębowska A., Rembisz, W. (2015b). Wprowadzenie do analizy inwestycji, produktywności, efektywności i zmian technicznych w rolnictwie, op. cit. pp. 24-25.

4. Bezat-Jarzębowska, A., Rembisz, W. (2016). Techniki wytwarzania jako endogenne uwarunkowanie produkcji i jej zmian w rolnictwie krajów UE. Monografie Programu Wieloletniego Nr 32 IERiGŻ-PiB, Warszawa.

5. Kleinhanss, W. (2014). Analiza konkurencyjności głównych typów gospodarstw rolnych w Niemczech, [in:] A. Kowalski, M. Wigier, B. Wieliczko (ed.), WPR a konkurencyjność polskiego i europejskiego sektora żywnościowego, IERiGŻ-PiB Program Wieloletni 2011-2014 nr 14.

6. Rembisz, W. (2005). Wynagrodzenie czynników wytwórczych w gospodarstwach rolnych. Zagadnienia Ekonomiki Rolnej, nr 4, Warszawa: IERiGŻ-PiB, pp. 24-43.

7. Rembisz, W., Floriańczyk, Z. (2014). Modele wzrostu gospodarczego w rolnictwie, IERiGŻ-PIB, Warszawa.

8. Rembisz, W., Waszkowski, A. (2017). Egzogenne uwarunkowania produkcji w rolnictwie - ceny czynników produkcji i wybrane wskaźniki makroekonomiczne, Program Wieloletni 2015-2019, nr 69, IERiGŻ-PiB, Warszawa.

9. Woś, A., Tomczak, F. (1983). Ekonomika rolnictwa. Zarys teorii. PWRiL, Warszawa. 